脳血管障害例に扣ける血液・酸素解離能と 脳循環代謝との関連についての研究

大阪大学医学部第一内科（指導阿部 裕教授）

長谷川建治

\title{
A STUDY ON THE RELATIONSHIP BETWEEN HEMOGLOBIN AFFINITY FOR OXYGEN AND CEREBRAL METABOLISM IN PATIENTS WITH CEREBROVASCULAR DISEASES
}

Kenji Hasegawa, MD

The First Department of Internal Medicine, Osaka University Medical School, Osaka

摡要 脳血管障害例に抽ける血液酸素解離能の变化の有無ならびに，その脳循環代謝に及ぼす影響に つき倹討する目的で以下の検討を行なつた。健常例21例, 脳血管障害例 30 例の血液酸素解離曲線を解 析し，へモグロビンが酸素により $50 \%$ 飽和される時点での酸素分圧を $\mathrm{P}_{50}\left(\right.$ 温度 $37^{\circ} \mathrm{C}, \mathrm{pH} 7.40, \mathrm{Pco}_{2}$ $36.6 \mathrm{mmHg}$ の条件下) として湘定し 血液酸素解離能の指標 とした．血液酸素解離能の関連因子とし て，赤血球内2,3-diphosphoglycerate，赤血球内pHの測定も併せ行なつた。また，脳血管障害例10例に ついて脳動静脈酸素含量較差, 脳酸素消費量および $\mathrm{CO}_{2}$ 変化に対する脳血管反応性の湘定を行ない, $\mathrm{P}_{50}$ との対比において検討した．脳血管障害例における $\mathrm{P}_{50}$ は健常例に比し，有意の高值を示し，その 程度は神経脱落症状の重篤のもの洼ど大であり，脳血管障害例に和ける血液酸素解離能の増大が示唆 された。しかしながら，この血液酸素解離能の增大は赤血球内2,3-diphosphoglycerate，赤血球内 pHの 変動を機序とするるのではないと考兄られた．神経脱落症状の重症度が一定の症例10例においては， 脳動静脈酸素含量較差㧍よび脳酸素消費量はそれぞれ $\mathrm{P}_{50}$ と有意正相関を示し，また， $\mathrm{CO}_{2}$ 変化に対 する脳血管反応性は脳酸素消費量, $\mathrm{P}_{50}$ のそれぞれと有意正相関を示した。脳血管障害の発症に伴ら血 液酸素解離能の増大は脳動静脈酸素含量較差扰よび脳酸素消費量を増加させる方向に作用することが 明らかとなり，脳循環代謝に占める血液酸素解離能の重要性が確認された。

\section{緒 言}

脳血管障害例における病態生理にかんしての今 日までの数多くの研究は, 主に, 酸素供給側とし ての血流の動態の検討および酸素需要側としての 組織代謝の変化の検討を中心として行なわれ，血 流と組織代謝の間に介在する血液の酸素解離能に

[昭和 52 年 7 月 23 日受稿]
かんしての研究は少ない。

しかしながら，脳組織は酸素消費が大なる故 に，特に血管障害時に打ける血液の酸素解離能の 変化の脳組織代謝に及ぼす影響は大であると考え られる。

本研究では，脳血管障害 (CVA) 時に抢ける血 液の酸素解離能の変化の有無を確認することおよ び酸素解離能の変化の脳循環代謝に及ぼす影響を 
検討することを目的として，CVA例に鸱ける血液 の酸素解離曲線oxygen dissociation curve (ODC) の測定およびODCの位置に影響を及ぼすと考え られている諸因子，即ち，赤血球内2,3-diphosphoglycerate (2,3-DPG), 赤血球内PH，へモグロビ ン $(\mathrm{Hb})$ ，動脈血がスの測定を行ならとともに， 脳血流量 $(\mathrm{CBF})$ ，脳動静脈酸素含量較差 $[(\mathrm{A}-\mathrm{V})$ $\left.\mathrm{O}_{2}\right]$, 脳酸素消費量 $\left(\mathrm{CMRO}_{2}\right), \mathrm{CO}_{2}$ 変化火 対す る脳血管反応性 $\mathrm{CO}_{2}$-reactivityな どの 脳循環代謝 諸量を測定し，血液の酸素解離能 (ODCの位置) との関連において検討を行ない，興味ある知見を 得るに至つた。

\section{対 象}

健常成人21例ならびにCVA例30例を対象として ODCの測定を行なつた．赤血球内2,3-DPG量，赤 血球内 $\mathrm{pH}, \mathrm{Hb}$, 動脈血ガスの測定は，表 1 に示す 症例数を対象として行なつた。臨床症状，脳血管 写, CT scan，脳波，髄液所見などより診断を得 たCVAのららわけは，脳硬塞17例，内顏動脈閉塞 症 7 例, 一過性脳虚血発作 3 例, 脳内出血 3 例で あつた．脳循環代謝諸量の測定は，CVA症例のう

表 $1 . \mathrm{P}_{50}$ および関連因子

\begin{tabular}{|c|c|c|c|c|}
\hline \multirow{2}{*}{\multicolumn{2}{|c|}{. }} & 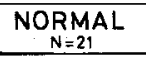 & C.V.A. & \multirow[b]{2}{*}{ SIGNIFICANCE } \\
\hline & & MEAN $\pm S . D$ & MEAN $=5 . D$ & \\
\hline${ }_{\text {(years) }}$ AGE & & $\begin{array}{c}44.5 \\
N=21 \\
N=2.2\end{array}$ & $\begin{array}{c}52.4 \pm 11.6 \\
N=30\end{array}$ & $p<0.025$ \\
\hline$H b_{g / d l}$ & : & $\begin{array}{c}15.32 \pm 0.81 \\
N=21\end{array}$ & $\underset{N=30}{1347 \pm 1.77}$ & $P<0.001$ \\
\hline 2.3-D.PG & & $\begin{array}{c}14.03 \pm 4.03 \\
N=21\end{array}$ & $11.95 \pm 290$ & $P<0.05$ \\
\hline$\triangle \mathrm{PH}$ & : & $\begin{array}{c}0.155 \pm 0.035 \\
N=8\end{array}$ & $\begin{array}{c}0.156 \pm 0.027 \\
N=8\end{array}$ & ns. \\
\hline $\mathrm{PaO}_{(\mathrm{mmHg})}$ & & $\begin{array}{c}88.0 \pm 15.2 \\
N=5\end{array}$ & $\begin{array}{c}84.3 \pm 18.7 \\
N=21\end{array}$ & n.s. \\
\hline$\underset{(\mathrm{mmHg})}{\mathrm{PaCO}_{2}}$ & & $\begin{array}{c}39.1 \pm 4.0 \\
\quad N=5\end{array}$ & $\underset{N=21}{37.2 \pm 4.9}$ & n.s. \\
\hline $\mathrm{PH}$ & $\because$ & $\begin{array}{c}7.413 \pm 0.032 \\
N=5\end{array}$ & $\begin{array}{c}7.428 \pm 0.044 \\
N=21\end{array}$ & n.s. \\
\hline $\mathrm{P}_{50}(\mathrm{mmng})$ & & $\begin{array}{c}27.50 \pm 0.75 \\
N=21\end{array}$ & $\begin{array}{c}30.04 \pm 1.87 \\
N=30\end{array}$ & $p<0.001$ \\
\hline
\end{tabular}

$\mathrm{Hb}$; hemoglobin. 2,3-DPG ; 2,3-diphosphoglycerate $\Delta \mathrm{pH}$; difference between extra-erythrocytic $\mathrm{pH}$ and intra-erythrocytic $\mathrm{pH} . \mathrm{P}_{50}$; oxygen tension at 50 per cent hemoglobin saturation. $N$; number of cases. n.s. ; not significant.
ち，一定の神経脱落症状の重症度，すなわち， hemiparesisを呈する群10名を対象とした。

\section{方法}

\section{1）血液酸素解離曲線（ODC）の測定}

Radiometer社製oxygen dissociation curve analyzer (DCA-1) を用い行なつた。被検者末梢血 $8 \mathrm{ml} D \mathrm{DCA}-10$ 測定室（液相）内に注入し，窒 素ガス $\left(\mathrm{CO}_{2} 4.79 \%\right.$ 含）にてdeoxygenationした 後, $\mathrm{O}_{2} 94.87 \%, \mathrm{CO}_{2} 5.13 \%$ 浱合ガスにて飽 和された気相に接触させ，その後の液相内の酸素 分王, $\mathrm{pH}$ ，および気相内の酸素分圧の変化を連続 的に測定，記録することによりODCを得た。得ら れたODCより，Hbか酸素により50\%飽和される 時点での酸素分王をpressure $50\left(\mathrm{P}_{50}\right)$ として測定 し, その血液のODCの位置, すなわb, 酸素解離 能を表わす指標とした。な拉，測定は温度 $37^{\circ} \mathrm{C}$ ， 炭酸ガス分王 $36.6 \mathrm{~mm} \mathrm{Hg}$ （1 気王下）の一定条件下 にて行ない， $P_{50}$ 値は次式により $\mathrm{pH} 7.40$ に補正し た值を用いた。

$\Delta \log \mathrm{P}_{50}=0.48 \Delta \mathrm{pH}$

2） $\mathrm{Hb}$ ，赤血球内2,3-DPG，赤血球内pHの測定

Hbの測定はシアンメトへモグロビン法により 行なつた。

赤血球内2，3-DPG量の測定は colorimetric法に よるSigma社製キット（kit No. 665-PA）を用い 行なつた。

赤血球内pHの測定はfrozen and thawによる榎 ら ${ }^{2)}$ の方法火従つた。

\section{3）脳循環代謝諸量の測定}

局所麻酔下にて，内埕動脈および内頝静脈を穿 刺し，ポリエチレン製カテーテル（内頝動脈；19 $\mathrm{G} \times 90 \mathrm{~mm}$, 内頚静脈；19 G × 150mm）を挿入, 留 犆し, 両者より動静脈血液ガス測定のための採血 を行ならととをに，内頝動脈カテーテルから CBF 測定のためのXe-133の注入を行なつた。なお， 内顤動脈の穿刺側は，細便塞症例については病篓 側，内頚動脈閉塞症例については健常側とし，内 頚静脈の穿刺側は病巣側とした。む，内頝静脈 内のカテーテルの先端は，透視下にて内啟静脈上 
球内にあることを確認した。

\section{i ) 脳血流量 (CBF) の測定}

Xe-133内頝動脈注入によるinitial slope analy$\operatorname{sis}^{3)}$ により施行した. 測定装圆, 演算方法について は，既報されている方法い従つた。CBFの測定 は各症例 とも安静時 (normoventilation) および 過呼吸時 (hyperventilation) それぞれについて行 なつた。即ち，安静時計測終了後15分後より過呼 吸を行なわしめ, 過呼吸開始後 3 分後に過呼吸時 CBFの測定を開始した。 また，CBF測定を行なつ たgamma scintillation cameraでの脳内関心領域 は病巣脑半球全体に設定した。な䄮，対象とした 内頝動脈閉塞症は全例とも, 注入側である健常側 から病巣側脳半球へのcross circulationが認めら れ, 関心領域は病巣脳半球内でXe-133が分布し た部分に設定した。

ii) $\mathrm{CO}_{2}$ 変化に 対する 脳血管反応性 $\left(\mathrm{CO}_{z^{-}}\right.$ reactivity) の算出

$\mathrm{CO}_{2}$-reactivityは次式により算出した。 ただし，

$$
\mathrm{CO}_{2} \text {-reactivity }=\frac{(\mathrm{CBFn}-\mathrm{CBFh}) \times 10^{2}}{\mathrm{CBFn} \times\left(\mathrm{PaCO}_{2} \mathrm{n}-\mathrm{PaCO}_{2} \mathrm{~h}\right)}
$$

CBFn ; normoventilation時 CBF $(\mathrm{ml} / 100 \mathrm{~g} / \mathrm{min})$ CBFh ; hyperventilation時 $\mathrm{CBF}(\mathrm{ml} / 100 \mathrm{~g} / \mathrm{min})$ $\mathrm{PaCO}_{2} \mathrm{n}$; normoventilation時 $\mathrm{PaCO}_{2}(\mathrm{~mm} H \mathrm{Hg})$ $\mathrm{PaCO}_{2} \mathrm{~h}$; hyperventilation侍 $\mathrm{PaCO}_{2}(\mathrm{~mm} H \mathrm{Hg})$

iii）血液ガス分析, 脳動静脈酸素含量較差 $\left[\left(\mathbf{A}^{-}\right.\right.$ V) $\mathbf{O}_{2}$ ] 脳酸素消費量 $\left(\mathbf{C M R O}_{2}\right)$, 脳二酸 化炭素排出量 $\mathrm{CO}_{2}$-efflux 測定

内頝動脈特よび内頝静脈に留置したカテーテ ルより，安静時おょび過呼吸時のCBF測定の 際, Xe-133注入後 1 分後に同時採血を行ない血液 $\mathrm{pH}, \mathrm{Po}_{2}, \mathrm{Pco}_{2}$ をadiometer社製血液ガス自動分析 装置 (ABL-II) にて測定し，酸素飽和度 $\mathrm{So}_{2}$ を Radiometer社製hemoximeter (OSM-II) Kて湘 定した。

酸素含量 $\mathrm{O}_{2}$ contentは次式により算出した。

$\mathrm{O}_{2}$ content $(\mathrm{ml} \mathrm{O} / \mathrm{dl})=\mathrm{Hb}(\mathrm{g} / \mathrm{dl}) \times 1.34$ $\times \frac{\mathrm{So}_{2}(\%)}{100}+3.13 \times 10^{-3} \times \mathrm{Po}_{2}(\mathrm{~mm} \mathrm{Hg})$

(A-V) $\mathrm{O}_{2}$ は次式により算出した.
(A-V) $\mathrm{O}_{2}(\mathrm{ml} \mathrm{O} / \mathrm{dl})=\mathrm{O}_{2}$ content, artery- $\mathrm{O}_{2}$ content, vein

$\mathrm{CMRO}_{2}$ は次式により算出した。

$\mathrm{CMRO}_{2}(\mathrm{ml} \mathrm{O} / 100 \mathrm{~g} / \mathrm{min})=\mathrm{CBF}(\mathrm{ml} / 100 \mathrm{~g} /$

$\min ) \times(\mathrm{A}-\mathrm{V}) \mathrm{O}_{2}(\mathrm{ml} \mathrm{O} / \mathrm{dl}) \times 10^{-2}$

全血中二酸化炭素含量 $\mathrm{CO}_{2}$ contentはSingerHasting nomogramに基づく Kelman ${ }^{5)}$ のcomputer programを用い算出した.

$\mathrm{CO}_{2}$-effluxは次式により算出した。

$\mathrm{CO}_{2}$-efflux $(\mathrm{ml} \mathrm{CO} / 100 \mathrm{~g} / \mathrm{min})=\mathrm{CBF}(\mathrm{ml} / 100$ $\mathrm{g} / \mathrm{min}) \times(\mathrm{V}-\mathrm{A}) \mathrm{CO}_{2}(\mathrm{ml} \mathrm{CO} / \mathrm{dl}) \times 10^{-2}$ ただし, (V-A) $\mathrm{CO}_{2}\left(\mathrm{ml} \mathrm{CO}_{2} / \mathrm{dl}\right)=\mathrm{CO}_{2}$ content, vein- $\mathrm{CO}_{2}$ content, artery

結 果

1) 血液酸素解離能とその関連血中因子

健常例21例の 平均年令は44.5才であり， $\mathrm{P}_{50}$ 平

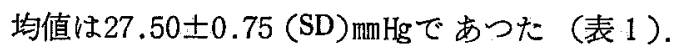
$\mathrm{P}_{50}$ を年令との関係につき見ると， $P_{50}$ と年令の間 には有意の相関は認められなかつたが，図 1 に示 すように， $P_{50}$ は高令者において低値を示す傾向 にあつた。

$\mathrm{CVA}$ 例30例の 平均年令は52.4才であり， $\mathbf{P}_{50}$ 平 均値は30.04士1.87mmHであつた（表 1 ）.

これは，健常例の $\mathbf{P}_{50}$ 平均值に比し，有意の高 值であつた $(\mathrm{P}<0.001)$. CVA例に打ける $\mathrm{Hb}$ 量, 2,3-DPG量はそれぞれ，13.47士1.77mg/dl, 11.95 $\pm 2.90 \mu \mathrm{M} / \mathrm{g}$. Hbといずれる CVA例が健常例に比 し，低值を示した。

一定条件下 (温度 $37^{\circ} \mathrm{C}, \mathrm{Po}_{2}=300 \mathrm{~mm} \mathrm{Hg}, \mathrm{Pco}_{2}=$

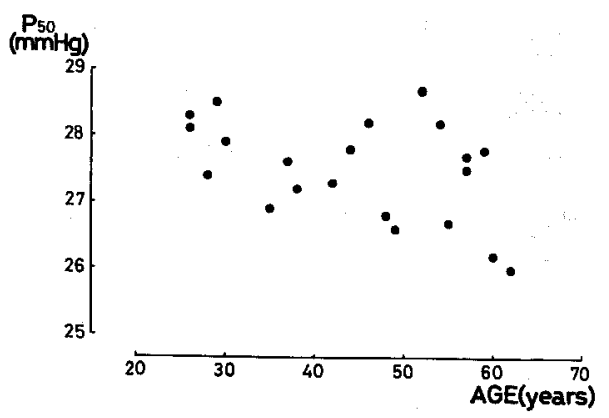

図 1，健常例におけると年 $\mathbf{P}_{50}$ 令の関係 


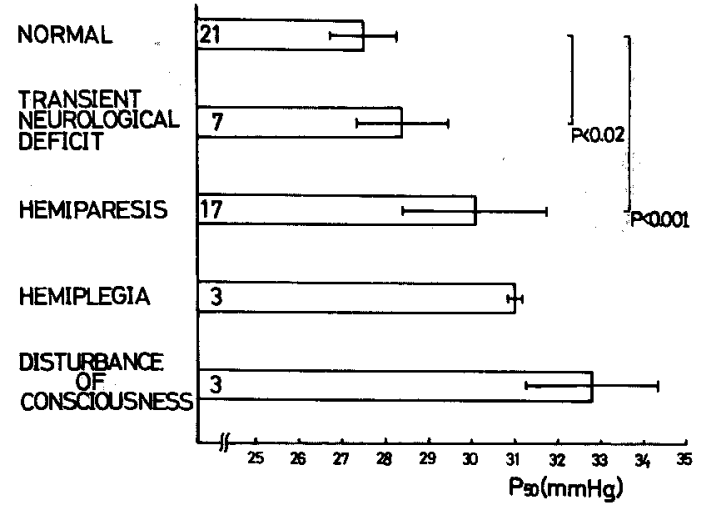

図 2．脑血管障害例における $P_{50}$ と神経脱落症状

$36.6 \mathrm{mmHg}$ ）に括ける血浆 $\mathrm{pH}$ と血球内pHの較差 $\Delta \mathrm{pH}$ は，健常例0.155土0.035，CVA例0.156士0.027 両者間に差は認められなかつた。

動脈血中の $\mathrm{Po}_{2}, \mathrm{Pco}_{2}, \mathrm{PH}$ は，表 1 に示寸如く， 健常例，CVA例間に差は認められなかつた。

2）CVA例における血液酸素解離能 と神経脱 落症状の関係
表 2、脳循環代搠諸量の測定症例

\begin{tabular}{|c|c|c|c|c|c|}
\hline & $\begin{array}{l}\text { AGE } \\
\text { (YEAR) }\end{array}$ & SEX & DIAGNOSIS & $\begin{array}{l}\text { DAYS } \\
\text { AFIEB } \\
\text { ONSEI }\end{array}$ & $\begin{array}{c}\text { MABP } \\
(\text { MMHG) }\end{array}$ \\
\hline $\begin{array}{l}\text { CASE- } 1: \\
\text { CASE- } 2: \\
\text { CASE- } 3: \\
\text { CASE- } 4: \\
\text { CASE- } 5: \\
\text { CASE- 6: } \\
\text { CASE- } 7: \\
\text { CASE- } 8: \\
\text { CASE- } 9: \\
\text { CASE-10 } \\
\text { MEAN } \\
\pm S . D .\end{array}$ & $\begin{array}{r}48 \\
48 \\
43 \\
53 \\
59 \\
49 \\
53 \\
50 \\
51 \\
52 \\
50.6 \\
4.2\end{array}$ & $\begin{array}{l}F \\
M \\
M \\
M \\
M \\
M \\
M \\
M \\
M \\
M\end{array}$ & $\begin{array}{l}\text { CT } \\
\text { ICAO } \\
C T \\
\text { ICAO } \\
\text { ICAO } \\
\text { CT } \\
\text { ICAO } \\
C T \\
C T \\
\text { ICAO }\end{array}$ & $\begin{array}{r}40 \\
105 \\
90 \\
75 \\
103 \\
107 \\
145 \\
99 \\
73 \\
110 \\
94.7 \\
27.9\end{array}$ & $\begin{array}{r}108 \\
109 \\
108 \\
99 \\
110 \\
112 \\
101 \\
117 \\
114 \\
103 \\
108.1 \\
5.7\end{array}$ \\
\hline
\end{tabular}

F ; female.M ; male.CT ; cerebral thrombosis. ICAO ; internal carotid artery occlusion. MABP ; mean arterial blood pressure measured at cerebral hemodynamic study.

CVA例における $\mathrm{P}_{50}$ を症例個々の神経脱落症状 の重症度につき分類した（図 2).

$P_{50}$ は，神経脱落症状が一過性にのみ出現した (transient neurological deficit) 群では28.41士 $1.07 \mathrm{mmHg}$ ，不全片麻㽻 (hemiparesis) を示した群 では30.05士1.69mm Hg，完全片麻痺 (hemiparesis)

表 3. $P_{50}$ と脳循環代謝諸量

\begin{tabular}{|c|c|c|c|c|c|c|c|c|c|c|c|c|}
\hline & & \multirow{2}{*}{ Pse } & \multicolumn{6}{|c|}{ NORMOVENTILATION } & \multicolumn{3}{|c|}{ HYPERVENTILATION } & \multirow{2}{*}{$\mathrm{CO}_{2}-\mathrm{R}$. } \\
\hline & & & $\mathrm{PaCO} 2$ & CBF & $(A-V) O_{2}$ & OMROe & COt-eff. & R.Q. & $\mathrm{PaCO}$ & CBF & COz-eff. & \\
\hline CASE- 1 & $:$ & 33.8 & 28.2 & 42 & 10,93 & 4.59 & 4.38 & 0.95 & 21.0 & 22 & 2.05 & 6.61 \\
\hline CASE- 2 & $:$ & 29.1 & 39.1 & 43 & 8.53 & 3.67 & 3.65 & 0.99 & 29.5 & 25 & 3.02 & 4.36 \\
\hline CASE- 3 & : & 31.9 & 36.2 & 54 & 8.19 & 4.42 & 3.16 & 0.71 & 28.2 & 28 & 1.92 & 6.01 \\
\hline CASE- 4 & $:$ & 28.9 & 34.4 & 39 & 9.35 & 3.65 & 2.44 & 0.67 & 27.8 & 28 & 3.13 & 4.27 \\
\hline CASE- 5 & $:$ & 28.8 & 43.8 & 44 & 8.02 & 3.54 & 2.64 & 0.75 & 31.1 & 28 & 3.69 & 2.86 \\
\hline CASE- 6 & $:$ & 28.0 & 45.4 & 32 & 8.60 & 2.75 & 2.15 & 0.78 & 27.1 & 18 & 3.87 & 2.39 \\
\hline CASE -7 & $:$ & 27.8 & 37.6 & 47 & 6.41 & 3.01 & 1.80 & 0.60 & .28 .1 & 34 & 3.28 & 2.91 \\
\hline CASE- 8 & $:$ & 29.2 & 40.8 & 45 & 7.10 & 3.20 & 2.45 & 0.77 & 31.0 & 28 & 3.41 & 3.86 \\
\hline CASE- 9 & $:$ & 29.5 & 37.8 & 43 & 7.16 & 3.08 & 2.63 & 0.85 & 25.8 & 28 & 2.90 & 3.01 \\
\hline CASE-10 & $:$ & 29.0 & 44.0 & $\stackrel{43}{=}$ & $\underline{7.18}$ & $\underline{\underline{3.59}}$ & 2.04 & $\stackrel{0.57}{=}$ & $\underline{35.0}$ & $\underline{23}$ & 2.56 & $\underline{\underline{3.45}}$ \\
\hline MEAN & $:$ & 29.60 & 38.73 & 42.2 & 8.147 & 3.550 & 2.734 & 0.764 & 28.46 & 26.2 & 2.983 & 3.973 \\
\hline $\pm S . D$. & $:$ & 1.85 & 5.17 & 6.4 & 1.316 & 0.591 & 0.790 & 0.137 & 3.67 & 4.4 & 0.647 & 1.392 \\
\hline
\end{tabular}

$\mathbf{P}_{50}$; oxygen tension at 50 per cent hemoglobin saturation $(\mathrm{mmHg}) \cdot \mathrm{PaCO}_{2} ;$ arterial carbon dioxide tension ( $\mathrm{mmHg}$ ). CBF ; cerebral blood flow (ml/100g/min.), (A-V) $\mathrm{O}_{2}$; arteriovenous oxygen difference $(\mathrm{ml} \mathrm{O} / \mathrm{dl}), \mathrm{CMRO}_{2} ;$ cerebral metabolic rate of oxygen ( $\mathrm{ml} \mathrm{O} / 100 \mathrm{~g} / \mathrm{min}$.). $\mathrm{CO}_{2}$-eff. ; carbon dioxide efflux $(\mathrm{ml} \mathrm{CO} / 100 \mathrm{~g} / \mathrm{min}$.). R.Q. ; respiratory quotient. $\mathrm{CO}_{2}$ R. ; $\mathrm{CO}_{2}$ reactivity $=\Delta \mathrm{CBF}(\%) / \Delta \mathrm{PaCO}_{2}$ 
を示した群では31.00土0.20m Hgであり, somnolence以上の意識障害を呈した (disturbance of consciousness) 群では32.80土1.55mmHgであつた。 即ら，CVA例における $\mathrm{P}_{50}$ は，神経脱落症状が重 篤のものほど, 高値を示す傾向にあつた.

3） CVA例における 血液酸素解離能と脳循環 代謝諸量の関係

CVA例で認められた $\mathrm{P}_{50}$ 高值のもつ, 脳偱環代謝 に占める意義を明らかとするため, 神経脱落症状 の重症度が一定の群, すなわち, hemiparesis群10 名に㧍ける $\mathrm{P}_{50}$ と以下の脳循環代謝諸量 との関係 につき検討した。これら10症例の年令, 性別, 診 断名, 発症よりの経過日数, 脳循環代謝諸量測定 時の平均血圧は表 2 に示す如くであつた。

\section{i) $\mathbf{P}_{50}$ टCMRO $\mathbf{C M}_{2}$ の関係}

$\mathrm{CMRO}_{2}$ 平均値は $3.55 \pm 0.59 \mathrm{ml} \mathrm{O} / 100 \mathrm{~g} / \mathrm{min}$. で あつたが (表 3)，これを $\mathrm{P}_{50}$ との対比において見 た. 図 3 に示した如く, $P_{50}$ が高值をとる症例 ほ ど $\mathrm{CMRO}_{2}$ は高値を示し, 両者間には有意の正相 関が成立した $(\mathrm{r}=0.8832, \mathrm{P}<0.001)$.

ii) $\mathbf{P}_{50}$ と $(\mathbf{A}-\mathbf{V}) \mathbf{O}_{2}$ の関係

(A-V) $\mathrm{O}_{2}$ 平均值は8.15 $11.32 \mathrm{ml} \mathrm{O} / \mathrm{d} 1$ であつ たが(表 3)，これを $P_{50}$ との対比に拈いて検討す ると, 図 4 に示す如く， $P_{50}$ が高值をとる症例ほ ど (A-V) $\mathrm{O}_{2}$ は高值を示し, 両者間汇，有意の 正相関が成立した $(r=0.6569, \mathrm{P}<0.05)$.

iii) $\mathrm{CMRO}_{2}$ \& $\mathrm{CO}_{2}$-reactivityの関係

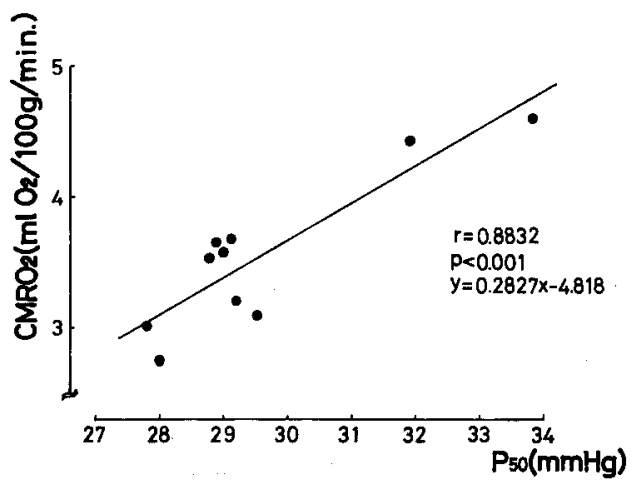

因 3、 $\mathrm{P}_{50}$ と $\mathrm{CMRO}_{2}$ の関係

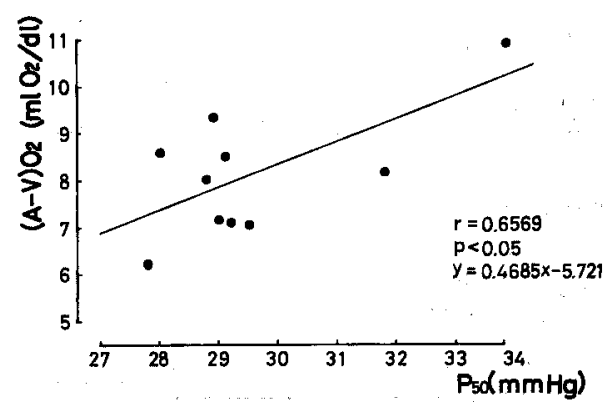

因 4. $\mathrm{P}_{50}$ と $(\mathrm{A}-\mathrm{V}) \mathrm{O}_{2}$ の関係

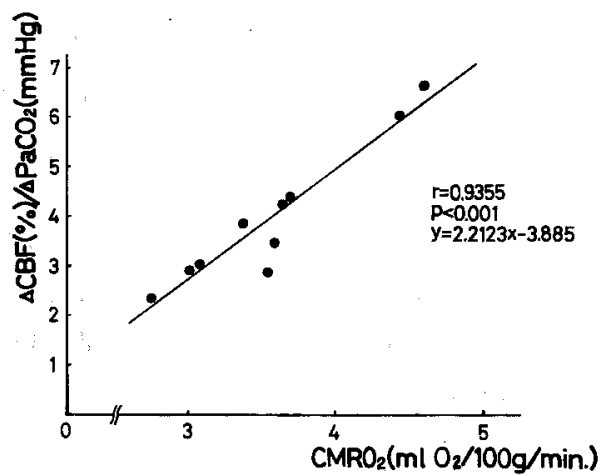

因 5. $\mathrm{CMRO}_{2}$ と $\mathrm{CO}_{2}$-reactivityの関係

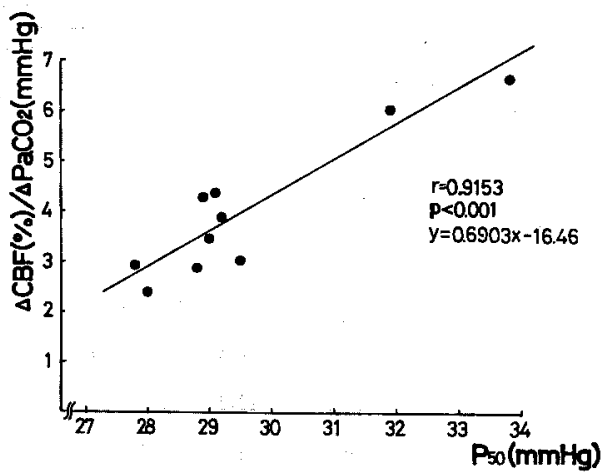

因 6. $\mathrm{P}_{50}$ と $\mathrm{CO}_{2}$-reactivityの関係

過呼吸に伴 万 $\mathrm{CBF}$ の減少度を $\mathrm{PaCO}_{2}$ の減少度と の比に怙いて見た $\mathrm{CO}_{2}$-reactivity $[\Delta \mathrm{CBF}(\%) / \Delta$ $\left.\mathrm{PacO}_{2}(\mathrm{mnHg})\right]$ と $\mathrm{CMRO}_{2}$ の関係を見ると, 図 5 亿示す如く, $\mathrm{CMRO}_{2}$ の高值を示す症例ほど， $\mathrm{CO}_{2}$-reactivityは大きく，両者間には有意の正相 関が成立した（r=0.9355, P<0.001). 


\section{iv) $\mathbf{P}_{50} \subset \mathbf{C O}_{2}$-reactivity 関係}

$\mathrm{CO}_{2}$-reactivity と $\mathrm{P}_{50}$ の関係を見ると，図6に示 す如く, $\mathrm{P}_{50}$ の高值の症例ほど, $\mathrm{CO}_{2}$-reactivityは 大きく，両者間には有意の正相関が成立した（ $r=$ $0.9153, P<0.001$ ).

\section{考案}

1）血液酸素解離能とその関連血中因子

健常例における $\mathrm{P}_{50}$ と年令の間には有意の相関 は認められなかつたすのの， $\mathrm{P}_{50}$ は，高令者では 低值をとる傾向が見られ（図 1)，高令者血の 酸素解離能 の低下が 示唆された。 Birnstingl ${ }^{6)}$ は, $\mathrm{Po}_{2}=9 \mathrm{~mm} \mathrm{Hg}$ と $\mathrm{Po}_{2}=13 \mathrm{~mm} \mathrm{Hg}$ でのHbの 酸素飽和 度 $\left(\mathrm{So}_{2}\right)$ を 40 才以下の群。および40才以上の群 で測定し， $\mathrm{Po}_{2}=9 \mathrm{~mm} \mathrm{Hg}, \quad \mathrm{Po}_{2}=13 \mathrm{~mm} \mathrm{Hg}$ のいすれに 特いても40才以上の群が 以下の群に比して $\mathrm{So}_{2}$ 力゙ $^{\circ}$ 大であることから高令者群に打ける血液酸素解離 能の低下が示唆されたとしているが，本研究で得 た結果は，同様の現象をより定量的に把握したも のと思われる。

CVA例30例の $\mathrm{P}_{50}$ 平均値は $30.04 \pm 1.87 \mathrm{~mm} \mathrm{Hg}$ と健 常例に比し有意の 高値を示し（表 1)，CVA例に 括けるODCは健常例のそれに比し，右方移動して いること，すなわち，血液酸素解離能が增大して いることが示唆され，さらに，その程度は神経脱 落症状が高度の群に括いてほど, 大であることが 確認された（図 2).

$\mathrm{ODC}$ 移動させる因子として $\mathrm{pH}$ ，温度， $\mathrm{Pco}_{2}$ などの環境因子の他に, Benesch ${ }^{7}$ およびChanutin $ら^{87}$ は，赤血球解糖系に存在する2,3-DPGがODC を右方移動させる作用を有することを明らかにし た. その後の研究で, 組織への酸素供給の低下 を共通病熊として有する疾患群，すなわち，貧 血，慢性肺疾患，先天性チフノーゼ性心疾患など で見られるODCの右方移動の際には，赤血球内 2,3-DPGの増量を伴らことが知られ，2,3-DPGの 増量が，これら疾患群で見られるODCの右方移動 を来たす原因であるとされている゙。

しかしながら，本研究で対象としたCVA例にお いて認められたODCの右方移動に際しては，赤血
球内2,3-DPGの増量は伴わなかつた（表 1)。従 って, CVA例でのODCの右方移動の機序にかんし ては他の因子を考党ねばならない。

本研究で対象としたCVA例は健常例に比して平 均年令は高く，Hb量は低値を示した。年令の ODCK及济す影響を考えると，健常例での $\mathrm{P}_{50}$ と 年令の関係（図 1) からも明らかな如く, 高令者 ではP $\mathrm{P}_{50}$ はむしろ 低值を示す傾向にあつたため， CVA例に和けるODCの右方移動は加令によるも のとは考えられないまた，Hb量については，貧 血で見られる如く，Hbの低值はODCの右方移動 を伴うことが知られているき. しかしながら，Hb の低值に伴うODCの右方移動の機序は2,3-DPGの 増量によるとされている"こと，また，CVA例で のb值と $P_{50}$ の相関を検討したところ，一定の関 係は認められなかつたことより，CVA例での健常 例に比してのHbの低値む，CVA例における $\mathrm{P}_{50}$ の 高值を説明し得るるのではないと考えられる。

本研究でのODCの 剆定は, 温度 $37^{\circ} \mathrm{C}, \mathrm{Pco}_{2}=$ $36.6 \mathrm{~mm} \mathrm{Hg}$ の一定条件下にて行ない， $\mathrm{P}_{50}$ 値は， $\mathrm{Hb}$ が酸素により $50 \%$ 飽和された時点での $\mathrm{Po}_{2}$ およ び血浆 $\mathrm{PH}$ 測定し，測定した $\mathrm{Po}_{2}$ をBohr俰数 0.48 を用いて $\mathrm{pH}=7.4$ の条件に補正して得たものであ る。しかしながら，pHによるODCの移動（Bohr効 果) は，敩密には赤血球内pHにより規定される ${ }^{10)}$ ため，血浆䟡を用いて $\mathrm{P}_{50}$ 值を補正する際には， 赤血球内PHに変動がないことが前提となる．健常 例， $\mathrm{CVA}$ 例それぞれの赤血球内 $\mathrm{pH}$ 一定条件下に て測定し，血浆 $\mathrm{pH}$ 血球内 $\mathrm{pH}$ 較差 $\Delta \mathrm{pH}$ 検討し たところ，両群間に差の認められなかつたこと は，結果に示した如くである（表 1).

Shappe1ら ${ }^{12}$ は，怗心症を有する患者で右心房 ペーシングを行ない，狭心症発作を誘発させる と， coronary sinusから採血した血液の $\mathrm{P}_{50}$ は有意 の上昇を示したものの，赤血球内2,3-DPG量・ $\mathrm{ATP}$ 量, 扎よび赤血球内pHの変動は, $\mathrm{P}_{50}$ の高値を 説明し得るものではなかつたとしている。また， Kostukら ${ }^{12)}$ は，心筋硬塞の患者群において，血液 の $\mathbf{P}_{50}$ の上昇を見出し，かつその程度は，心不全 
表 4 。血球・血槳成分の圈換に伴 $P_{50}$ の变化

\begin{tabular}{|c|c|c|c|c|}
\hline & \multirow{2}{*}{$\frac{\mathrm{Hb}}{\mathrm{g} / \mathrm{dl}}$} & \multirow{2}{*}{$\frac{P_{s 0}}{\mathrm{mmHg}}$} & \multirow{2}{*}{$\frac{2.3-D P G}{\mu \mathrm{M} / \mathrm{gHb}}$} & \multirow{2}{*}{$=\frac{\Delta P H}{=P H_{e}-P H_{l}}$} \\
\hline & & & & \\
\hline$N-R B C+N-P L A S M A$ & $: 11.7$ & 24.8 & 17.4 & $0.13=7.31-7.18$ \\
\hline$P-R B C+P-P L A S M A$ & $: \quad 9.9$ & 30.9 & 15.4 & $0.21=7.40-7.19$ \\
\hline N-RBC + P-PLASMA & : 11.9 & 26.4 & - & $0.20=7.37-7.17$ \\
\hline$P-R B C+N-P L A S M A$ & : $\quad 9.9$ & 30.3 & 一 & $0.15=7,36-7,21$ \\
\hline
\end{tabular}

$\mathrm{N}-\mathrm{RBC}$; red blood cell in a normal subject. $\mathrm{N}$ plasma ; plasma in a normal subject. P-RBC; red blood cell in a patient with cerebral thrombosis.P-plasma ; plasma in a patient with cerebral thrombosis, PHe ; extra-erythrocytic PH. PHi; intraerythrocytic $\mathrm{PH}$.

などの臨床症状の重篤なものほど大であると報告 したが，赤血球内2,3-DPG量およびATP量の増加 は認められなかつたとしている，従つて，CVA例 でのODCの右方移動の機序は，これらの報告に 見られる狭心症ないしは心筋硬塞に打けるそれと 類似のものかもしれない.

$\mathrm{PH}, \mathrm{Pco}_{2}$ ，赤血球内2,3-DPG量， $\mathrm{ATP}$ 量などの 他に, catecholamine, cortisoneなど13)のホルモン

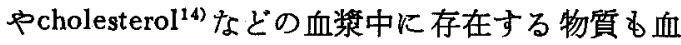
液の酸素運般能に影響を与える事が示唆されてい る。

本研究で認められたCVA例におけるODCの右 方移動の原因が；血球，血浆いずれの成分の変化 によるものかを検討するため，血液型の同一の健 常人血および，脳硬塞患者血を用いて表 4 に示す 如くに血球成分と血浆成分を入机か党た際の $\mathrm{P}_{50}$ 值および，その関連因子の測定を行なつた。

健常人赤血球 (N-RBC) と健常人血将 (Nplasma) の組合せではP $\mathrm{P}_{\mathrm{s}}$ は2 $24.8 \mathrm{~mm} \mathrm{Hg}$ あ゙あり， 患者赤血球 (P-RBC) と患者血浆 (P-plasma) の組合せでは $\mathrm{P}_{50}$ は $30.9 \mathrm{~mm} \mathrm{Hg}$ 患者血が健常人血 に比し $P_{50}$ は高值であつた．N-RBCとP-plasma の組合せでは $\mathrm{P}_{50}$ は26.4mm Hgであり，P-RBCとNplasmaの組合せでは $\mathrm{P}_{50}$ は30.3mm Hgであつた。 すなわち，血盌成分の入れかえにより， $\mathrm{P}_{50}$ は軽 度变化を示するのの， $P_{50}$ 值に密接に関与するの
は血球成分そのむのであると考えられた。

2）CVA例における 血液酸素解離能と脳循環 代謝諸量の関係

CVA例に拈けるODCの右方移動（ $\mathrm{P}_{50}$ の高値） のもつ，脳循環代謝に扣ける意義を明らかとする ため, 神経脱落症状の重症度が一定の群, すなわ ち, hemiparesisの症例10例における $\mathrm{P}_{50}$ と脳循環 代謝諸量の関連を検討した。

先ず， $\mathrm{CMRO}_{2}$ と $\mathrm{P}_{50}$ の間には，図 3 に示す如 く有意の正相関が得られた。 $\mathrm{CMRO}_{2}$ は $\mathrm{CBF}$ と (A-V) $\mathrm{O}_{2}$ との積からなるため, 得られた $\mathrm{CMRO}_{2}$ とP $\mathrm{P}_{50}$ 間の 正相関は， $\mathrm{P}_{50} か ゙ C B F ，(A-V) \mathrm{O}_{2}$ のい ずれと相関することにより成立したかを見るた め， $\mathrm{P}_{50}$ とCBF， $\mathrm{P}_{50}$ と (A-V) $\mathrm{O}_{2}$ それぞれの相関 関係を検討したところ， $\mathrm{P}_{50}$ とCBF間には有意の 相関は認められなかつたが， $\mathrm{P}_{50}$ と (A-V) $\mathrm{O}_{2}$ 間 には，因 4 に示す如く，有意の正相関が得られ

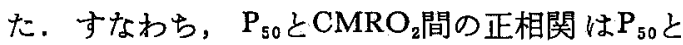
(A-V) $\mathrm{O}_{2}$ が正相関することにより成立したもの と考えられる。

CVAの発症によりもたらされるCBFの低下は， 組織のhypoxiaを来たし，この組織のhypoxiaすな わち, 組織での酸素分圧の低下に伴い(A-V) $\mathrm{O}_{2}$ が 增大することは，諸家 ${ }^{15)}$ 報告より明らかであ る、CBFが低下した際に，生体は代償的に(A-V) $\mathrm{O}_{2}$ を増大せしめて脳組織への酸素供給量 $\mathrm{CBF} \times$ (A-V) $\mathrm{O}_{2}$ を一定に維持 寸べく働くものと思われ る. 本研究で明らかとなつた如く, CVA発症に伴 い, ODC $の$ 右方移動（血液酸素解離能の増大） が生じると，脳組織 のhypoxiak伴つて扰こる (A-V) $\mathrm{O}_{2}$ の増大に加えて, さらなる (A-V) $\mathrm{O}_{2}$ の 増大が期待できる.CVA症例で神経脱落症状の重 症度が一定の群に扎いて， $\mathrm{P}_{50}$ と (A-V) $\mathrm{O}_{2}$ 間, $\mathrm{P}_{50}$ と $\mathrm{CMRO}_{2}$ 間それぞれで有意の正相関が得られ たことは，臨床例において，ODCの右方移動のも つ循環生理学的意義を明らかにするとともに，脳 血管障害時の脳組織への酸素供給にかんしての上 述の推論を重付けるものと考える。

らなみに，ODCの右方移動がすたらす（A-V) 


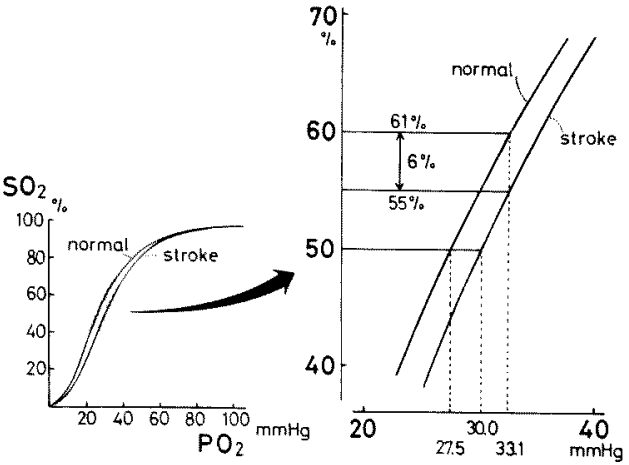

図 7. 血液酸素解離曲線 の右方移動に伴 $5 \mathrm{O}_{2}$ saturationの变化

$\mathrm{O}_{2}$ の増加度を試算するために，図 7 に $\mathrm{P}_{50}=27.5$ $\mathrm{mm} \mathrm{Hg}$ (健常例での平均値) と $\mathrm{P}_{50}=30.0 \mathrm{~mm} \mathrm{Hg}$ (CVA 例での平均值) のODCを示した。 CVA例における 動脈血 $\mathrm{Po}_{2}$ 平均值 $84.3 \mathrm{~mm} \mathrm{Hg}$ お よび内頝静脈血 $\mathrm{Po}_{2}$ 平均値 $33.1 \mathrm{mmHg}$ を用いて動静脈間の酸素飽和度差 を求めると，健常例のODCでは95-61=34(\%), CVA例のODCでは95-55=40（\%)となり, CVA 例のODCは健常例のそれに比し，(40-34) $\times$ $\frac{100}{34}=18(\%)$ 多く酸素を供給し得ることとな る。

次に， $\mathrm{P}_{50}$ と有意の正相関関係にあつた $\mathrm{CMRO}_{2}$ と $\mathrm{CO}_{2}$-reactivityとの関係を検討した結果, 両者 間には有意の正相関が成立した（図５）。すなわ ち，脳への酸素供給がよく保たれた症例汪ど， $\mathrm{CO}_{2}$ 変化に対する脳血管反応性そのものも大であ る傾向が認められた． $\mathrm{CO}_{2}$-reactivityは，血圧変 化に対するCBFのautoregulationとならんで脳循 環の自己調節機構として重要であるといつた生理 学的意義からのみならず, $\mathrm{CO}_{2}$ 変化させてCBF を変化させることにより治療効果を期待できる こと，和よび， $\mathrm{CO}_{2}$-reactivityから他の血管作動 性薬剤に対する脳血管反応性を推測し得 ること などの治療学的意義からす，脳循環にかんしての 研究において重要な命題とされており，特に， $\mathrm{CO}_{2}$-reactivityに関与する 修飾因子の 解明に多大 の努力が払われている ${ }^{16)}$.

本研究では，前述の如く， $\mathrm{P}_{50}$ と正相関関係に

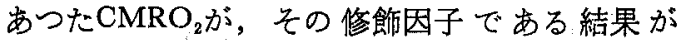
得られ，Fujishima ${ }^{17)} ら も ，$ 同様の報告をしてい る。

CVA例に扔いて, $\mathrm{CMRO}_{2} か ゙ \mathrm{CO}_{2}$-reactivityを修 飾する機序は，いかなるるのであるらか。

CVA例に打いては，組織への酸素供給の低下に 伴い，脳組織での全解糖系に占める嫌気的解糖の 割合が増大することが知られている。事実，本研 究で対象としたCVA例10例の呼吸商 (RQ) 平均 值は0.76であり，文献上の正常值 ${ }^{15)} 0.95 \sim 0.99$ K 比し低值であり，これら症例に括ける旗気的解糖 の六進が示唆された。 また，嫌気的解糖の六進 は，組織でのacid metaboliteの上昇を来たし，さ らにacid metaboliteの上昇は; 組織緩衝系の中の bicarbonate buffer systemからの $\mathrm{CO}_{2}$ 遊離を来た し，組織緩衝系の変化をひき抗こことが示唆さ れている18).

そこで，CVA例において $\mathrm{CMRO}_{2}$ が $\mathrm{CO}_{2}$-reactivityを修飾する一機序として，酸素供給の低下に 伴う組織緩衝系の変化を想定し, 組織緩衝系の变 化を示すindex と $\mathrm{CMRO}_{2}$ の関係，および，その index と $\mathrm{CO}_{2}$-reactivityの関係を検討することとし た.

過呼吸に伴 $5 \mathrm{CO}_{2}$ 排出量 $\left(\mathrm{CO}_{2}\right.$-efflux $)$ と $\mathrm{CMRO}_{2}$ との関係を見ると, 図 8 に示す如く, 両者間に は有意の負相関が得られた $(\mathrm{r}=-0.8418, \mathrm{P}<$

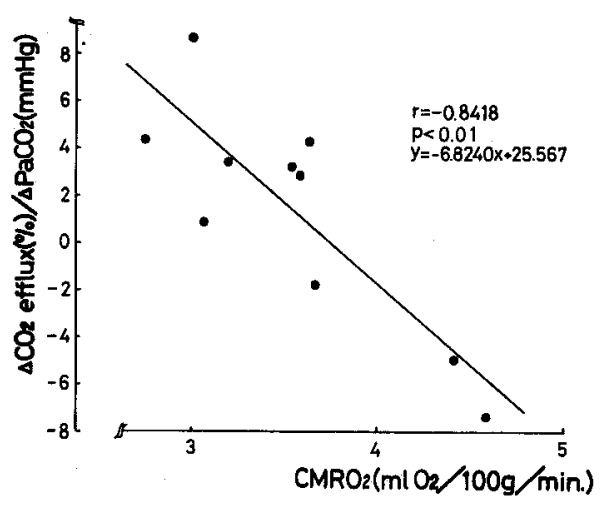

図 8. $\mathrm{CMRO}_{2}$ と過呼吸に伴 5 $\mathrm{CO}_{2}$-efflux増加度の 関係 


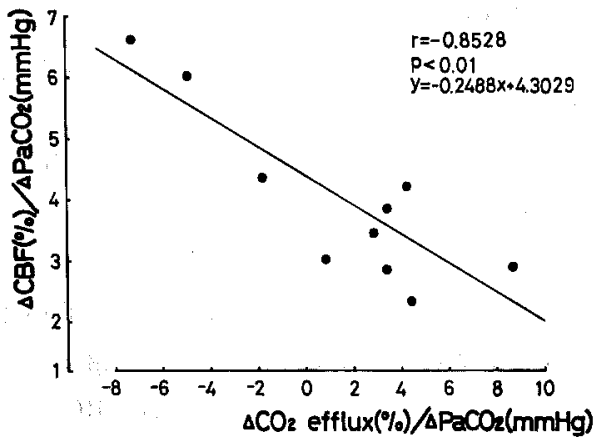

図 9.過呼吸に伴 $5 \mathrm{CO}_{2}$-efflux增加度と $\mathrm{CO}_{2}$-reactivityの関保

0.01)。過呼吸を行ならと, 組織のbicarbonate から酸化反応関係のない $\mathrm{CO}_{2}$ が排出されるこ とが知られている $\mathrm{CO}_{2}$-effluxの大なる症例は，組織でのbicarbonate buffer systemからのCO れる。すなわち，この結果は， $\mathrm{CMRO}_{2}$ が小なる 症例汪ど過呼吸に伴 $\mathrm{CO}_{2}$-effluxが大であること を示し，さらには，組織でのbicarbonate buffer systemからのCO $\mathrm{CO}_{2}$ 離が大であることを示唆する るのと考えられる．次に過呼吸に伴 $5 \mathrm{CO}_{2}$-efflux の增加度と $\mathrm{CO}_{2}$-reactivityとの関係を見ると, 図 9 に示主如く, 両者間には有意の負相関が成立し た $(r=-0.8528, P<0.01)$. 図9の結果は, 過

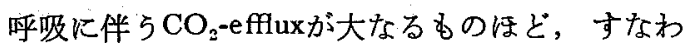
ら, 組織でのbicarbonate buffer systemからのCO 遊離が大なるものほど $\mathrm{CO}_{2}$-reactivityは低值とな ることを示唆するものと考点られる。

以上の結果は， $\mathrm{CVA}$ 例に和いては $\mathrm{CMRO}_{2}$ の変 化が組織緩衝系の変化を介して $\mathrm{CO}_{2}$-reactivityそ のものにも影響する事実を示唆するるのであると 考えられる。

本研究では，CVA発症に伴い惹起されるODC の右方移動（血液酸素解離能の増大）は(A-V) $\mathrm{O}_{2}$ を増大させることにより $\mathrm{CMRO}_{2}$ を増大せしめ ている可能性が示唆され，さらには， $\mathrm{CMRO}_{2} か ゙$ 大の症例は $\mathrm{CO}_{2}$ 変化に対する脳血管反応性る大と なることが明らかとなつた。これらの新知見は，
脳血管障害時の脳循環代謝飞占める血液酸素解離 能の変化の重要性を示唆するとともに, 脳血管障 害の病態解明, 特に, 脳酸素消費量の把握の際に は血液酸素解離能の把握を前提とすべきことを示 すむのである．屯た，血液酸素解離能の増大と脳 酸素消費量とが 正相関するといら結果を考える 時, 薬物投与により血液酸素解離能を変化させる 可能性が示唆されている ${ }^{20)}$ 現在では, 脳血管障害 に括ける脳組織への酸素供給の修復を血液酸素解 離能の增大により行なら, 新しい治療面の展開が 期待できるるのと考えられる。

\section{結 論}

脳血管障害例に括ける血液酸素解離能の変化の 有無ならびに，その脳循環代謝に及ぼす影響を検 討する目的で, 健常例21例, 脳血管障害例30例を 対象として血液酸素解離曲線, 赤血球内2,3-DPG 赤血球内 $\mathrm{pH}$ の測定を行ならととるに，脳血管障害 例10例の脳循環代謝諸量の測定を行ない, 血液酸 素解離曲線の位置 $\left(\mathrm{P}_{50}\right.$ 值) との対比に和いて検 討し，以下の結論を得た.

1）脳血管障害例では，健常例に比し，血液酸 素解離曲線の有意の右方移動 ( $\mathrm{P}_{50}$ 高值) を示し, その程度は, 神経脱落症状の重篤のものほど, 大 であつた。

2）脳血管障害例に和ける血液酸素解離曲線の 右方移動は, 赤血球内 $2,3-\mathrm{DPG}$ 量, 赤血球内 $\mathrm{pH}$ 変動を機序とするるのとは考えられなかつた。

3）脳動静脈酸素含量較差扣よび脳酸素消費量 は，それぞれ $\mathrm{P}_{50}$ 值と有意の正相関を示した。

4) 脳血管障害の発症に伴い惹起される, 血液 酸素解離能の増大は, 脳動静脈酸素含量較差を増 大させることにより脳酸素消費量を增加させる方 向に働くことが示唆された.

5）動脈血 $\mathrm{CO}_{2}$ 分王変化に対する，脳血管反応 性は，脑酸素消費量吅よび $\mathrm{P}_{\mathrm{s} 0}$ 值と有意の正相関 を示した。

6）脳血管障害例においては，脳酸素消費量の 変化が, 脳組織の緩衝系の变化を介して, $\mathrm{CO}_{2}$ 変 化に対する脳血管反応性に影響している可能性が 
示唆された。

謝辞 稿を終えるにあたり，血溜酸案解離曲線の測 定，その他にかんし，終始，御教示を睗わつた大阪大学 医学部第一生理学教室, 中馬一郎教授に心からの謝意を 表します。

\section{文献}

1) Duvelleroy MA, et al: An oxyhemoglobin dissociation analyzer. J Appl Physiol 28: 227, 1970.

2) Enoki, $Y$, et al: A simple method for determination of red cell intracellular PH J Physiol Soc Japan 34: $761,1972$.

3) Olesen J, et al: Regional cerebral blood flow in man determined by the initial slope of the clearance of intraarterially injected Xe-133. Stroke 2: 519, 1971.

4）青山 喬：脳硬塞症例の非閉塞部位における脳 循環に関する研究. 脳之神経 $28: 1207,1976$.

5) Kelman GR: Digital computer procedure for the conversion of $\mathrm{PCO}_{2}$ into blood $\mathrm{CO}_{2}$ content. Resp Physiol 3: 111, 1967.

6) Birnstingl $M$, et al: Variations in oxyhemoglobin dissociation with age, smoking, and Burger's disease. Brit J Surg 54: 615, 1967.

7) Benesch $R$ and Bensesch RE: The effect of organic phosphates from erythrocytes on the allosteric properties of hemoglobin. Biochem Biophys ResCommun 26: 162, 1967.

8) Chanutin A and Curnish RR: Effect of organic and inorganic phosphates on the oxygen equilibrium of human erythrocytes. Arch Biochem Biophys 121: 96, 1967.

9) Finch $C A$ and Lenfant C: Oxygen transport in man. N Engl J Med 286: 407, 1972.
10) Hilpert $P$, et al: The Bohr effect related to blood and erythrocytes. PH Amer J Physiol 205: 337, 1963.

11) Shappel SD, et al: Acute changes in hemoglobin affinity for oxygen during angina pectoris. $\mathrm{N}$ Engl J Med 282: 1219, 1970.

12) Kostuk WJ, et al: Altered hemoglobin oxygen affinity in patients with acute myocardial in farction. Amer J Cardiol 31: 295, 1973.

13) Bauer $\mathrm{CH}$, et al: The influence of aldosterone and cortisol on oxygen affinity and cation concentration of the blood. Resp Physiol 5: 360, 1968.

14) Steinbach JH, et al: High blood cholesterol reduces in vitro blood oxygen delivery. J Surg Res 16: $134,1974$.

15) Welch KMA and Meyer JS: Disordered cerebral metabolism after cerebral ischemia and infarction. Therapeutic implications. Meyer, JS, ed. Modern concepts of cerebrovascular disease, Spectrum publications Inc, New York, 1975, p 87

16) Olesen J: Cerebral blood flow, methods for measurements, regulation, effects of drugs, and changes in disease. Acta Neurol Scand, suppl. 57, p 1, 1974.

17) Fujishima $M$, et al: The relation between cerebral oxygen consumption and cerebral vascular reactivity to carbon dioxide. Stroke 2: 251, 1971.

18) Meyer JS, et al: Abnormal hemispheric blood flow and metabolism in cerebrovascular disease, $i$ Disordered patterns of hemispheric metabolism. Stroke 3: 141, 1972.

19)間田直幹, 内溒耕二：新生理学,下巻, 医学畫 院，東京， 1965. p. 588.

20) Brewer G: 2,3-DPG and erythrocyte oxygen affinity. Ann Rev Med 25: 29, 1974. 